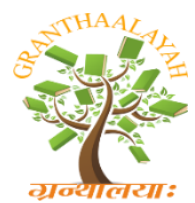

\author{
INTERNATIONAL JOURNAL OF RESEARCH \\ GRANTHAALAYAH \\ A knowledge Repository
}

Science

\title{
MEDICAL STUDENT'S KNOWLEDGE, ATTITUDES AND PERCEIVED BARRIERS TOWARDS RESEARCH: A STUDY AMONG NEPALESE STUDENTS
}

\author{
Sudarshan Paudel ${ }^{1}$, Krishna B GC ${ }^{1}$, Balakrishnan M Acharya ${ }^{2}$ \\ ${ }^{1}$ School of Public Health, Patan Academy of Health Sciences, Nepal \\ ${ }^{2}$ School of Medicine, Patan Academy of Health Sciences, Nepal
}

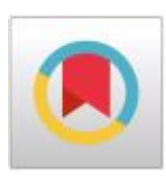

\begin{abstract}
Background: Undergraduate research exposure leads to academically dexterous and professionally unbeaten physicians. Undergraduate medical courses have research curriculum in Nepal but little is known about how students perceive research. The aim of this survey was to assess the knowledge, attitudes and perceived barriers towards research among medical students at Patan Academy of Health Sciences Nepal.

Method: A cross-sectional survey based on a questionnaire applied to 253 undergraduate medical students from year two to six enrolled in Patan Academy of Health Sciences, Nepal.

Results: The response rate was $97 \%$. Majority respondents $(78.3 \%)$ have viewed that medical curriculum demands sincere dedication and effort at the cost of research funding $(71.5 \%)$, allocated time for research $(61.7 \%)$, well-equipped laboratory and technologies. Besides that, ethical approval $(47.8 \%)$, administrative approval $(46.6 \%)$ and supportive staff $(41.1 \%)$ are other barricade to research.

Conclusion: The students have positive perception and attitude towards research. They have faced some barriers thus college needs to train students in research and provide supervision in a small research project. This model would improve academic learning, skills acquisition, encourage student interest in research, reduce barriers to student research and make better use of limited resources.
\end{abstract}

Keywords: Undergraduate Medical Students, Research, Perceived Barriers, Nepal.

Cite This Article: Sudarshan Paudel, Krishna B GC, and Balakrishnan M Acharya. (2019). "MEDICAL STUDENT'S KNOWLEDGE, ATTITUDES AND PERCEIVED BARRIERS TOWARDS RESEARCH: A STUDY AMONG NEPALESE STUDENTS." International Journal of Research - Granthaalayah, 7(2), 162-170. 10.29121/granthaalayah.v7.i2.2019.1017.

\section{Introduction}

Medical professionals bear immense pressure from society to be polymath personality. University system had been training medical professional biomedical knowledge and skills through various teaching learning approaches (WFME, 1998). But preparing medical students to meet the changing 
needs of society remained always great challenge (Zeir, 2006). Hence, modern medical education has tried to preserve the triad between services, teaching and research (Oliveira, 2013), (Vereilken, 2017).

Besides others, research has gained obligatory value in modern medical education (DeFranco, 2014), (Bennett, 2016). Medical schools train students in research to meet accreditation standard and excel in career because research is skewed to postgraduate research initiatives as well (Lloyd, 2004), (Reinders, 2005), (Alghamdi, 2014). Research not only hoist evidence-based medical practice but also lend a hand to convey new findings within (as well as outside) medical fraternity (Aslam, 2005), (Abu-Zaid, 2013), Osman, 2016). Academic and practical exposure of research to medical students boosts confidence to apply the scientific process, infer results, explain results and apply as appropriately (Bennett, 2016), (Stone, 2018). There is still long way to go to infuse research culture among medical students to fight the battle against the potential health problems (Aslam, 2005), (Silcox, 2006), (Stone, 2018).

Developing countries has given low priority in health researches (Nuyens, 2007), (McGregor, 2014). In global repository of health research, South Asia contributes only $1.2 \%$ which is insignificant output (Gharaubeh, 2014). This shows the pitiable number of physician-scientists in medical practice (Lloyd, 2004), (Solomon, 2002) that rouse professional stagnation in clinical and basic science knowledge (Siemens, 2010), Donika, 2015). The possible reason behind such condition might be inadequate research exposure, less financial incentive, dedicated time for research work (APEC, 2010).

Since research is stipulated as competencies of undergraduate medical program in its graduates at Patan Academy of Health Sciences, Nepal (PAHS, 2008) but no study has yet been conducted to assess this outcome. Hence, this study was embarked to measure the knowledge, attitudes and perceived barriers to research among medical students.

\section{Methods}

The cross-sectional study was conducted at PAHS in 2017. The respondents were 253 undergraduate medical students in their second to sixth academic years. PAHS is a public institution where triads of 'education, service and research' are key action words in its mission statement. Since PAHS was founded in 2008, its medical curriculum was tailor made taking lessons from conventional medical schools within country and abroad. Unlike other medical schools, the curriculum is structured in four parts namely, three months foundation course, 24 months basic health sciences, 30 months applied health sciences and 12 months of internship. The foundation course gives overview of the public health course and essential clinical skills like history taking, medical humanities. In the basic sciences, students are taught clinical oriented basic sciences course and community health sciences (public health courses along with research methods, biostatistics).

The academic contents are delivered at PAHS through Problem Based Learning (PBL) and Clinical Presentation (CP) along with few didactic sessions. Almost one-fourth portion curriculum is executed at different levels of health care system of the country. Students prepare reports based 
on their field works and have to defend their report. Besides that, students carry out two research projects in group. One of them is quality of care in clinical settings.

The students who have completed Principle of Human Biology (PHB) part one (first year of Basic Sciences) were eligible for the study. They get some theoretical knowledge and practice during that period. They prepare report based on community-based learning and education report. Hence, there were 310 students from five batches eligible for the study.

The research team briefed the research concept and seeks their concept to participate as respondent. The research questionnaire was distributed during pre-field community postings orientation held in 2017 to different batches. The research instrument was adopted with permission of Tarig Osman from Sudan (Osman, 2016). It was a self-administered questionnaire containing two sections; demographic information of respondents and knowledge, attitude and perceived barriers to research. The research section comprised five domains fifty dichotomous statements. The statements were related to perceptions to research; motives for conducting research; reasons for pursuing research career; reasons for not pursuing research career; and barriers to research. In an additional; it included 10 questions on competency of research supervisor. The filled questionnaire was collected next day.

Descriptive frequency analysis was performed for all variables in the questionnaire. Chi-squared tests were conducted to investigate the association between gender and among batches regarding perceptions to research.

\section{Results}

The response rate was $81.6 \%(\mathrm{n}=253)$. The majority respondents were male $(61.3 \%)$. Among all, $22.1 \%$ were from second years whilst $15.9 \%$ were from period of education. Majority $(87.7 \%)$ respondents had no prior research experience before joining medical school. The mean age \pm SD was $22.83 \pm 2.574$ years.

Table 1: Demographic description of respondents $(\mathrm{N}=253)$

\begin{tabular}{|c|l|l|l|}
\hline \multicolumn{1}{|c|}{ Description } & \multicolumn{1}{|c|}{ Details } & Freq & \multicolumn{1}{c|}{ \% } \\
\hline \multirow{2}{*}{ Sex } & Male & 155 & 61.3 \\
\cline { 2 - 4 } & Female & 98 & 38.7 \\
\hline \multirow{3}{*}{ School } & Rural & 118 & 46.6 \\
\cline { 2 - 4 } & Urban & 135 & 53.4 \\
\hline \multirow{2}{*}{ Education (PCL level) } & Public & 104 & 41.1 \\
\cline { 2 - 4 } & Private & 149 & 58.9 \\
\cline { 2 - 4 } & $10+2$ & 246 & 97.2 \\
\cline { 2 - 4 } & Health Sciences & 7 & 2.8 \\
\hline \multirow{5}{*}{ Academic year of study } & $2^{\text {nd }}$ year & 56 & 22.1 \\
\cline { 2 - 4 } & $3^{\text {rd }}$ year & 54 & 21.3 \\
\cline { 2 - 4 } & $4^{\text {th }}$ year & 50 & 19.8 \\
\cline { 2 - 4 } & $5^{\text {th }}$ year & 53 & 20.9 \\
\cline { 2 - 4 } & $5^{\text {th }}$ year+ (interns) & 40 & 15.9 \\
\hline \multirow{2}{*}{ Prior research experience } & No & 222 & 87.7 \\
\cline { 2 - 4 } & Yes & 31 & 12.3 \\
\hline
\end{tabular}


Regarding the significance of research, almost all students viewed that it is work doing to the practice medicine. Students have appraised the medical curricula demanding student led research $(94.1 \%)$. More than three-forth $(79.8 \%)$ respondents have argued that having research experience is an important criterion for residency training in medicine after graduation. Many (60.9\%) respondents viewed; preparing an article (ready to submit for publication) would be a requirement for partial fulfillment of the MBBS degree.

Table 2: Reasons for pursuing a career in research and not pursuing a career in research

\begin{tabular}{|c|c|c|c|c|c|}
\hline $\begin{array}{l}\text { Reasons for pursuing a career in research }(n= \\
93)\end{array}$ & 2year & 3year & 4year & 5year & 5yeart \\
\hline it will elevate professional standing as a clinician & $20.5 \%$ & $18.1 \%$ & $14.5 \%$ & $22.9 \%$ & $24.1 \%$ \\
\hline it gives pleasure & $23.2 \%$ & $15.9 \%$ & $12.2 \%$ & $24.4 \%$ & $24.4 \%$ \\
\hline $\begin{array}{r}\text { there are no emergency, clinical duties and on- } \\
\text { calls }\end{array}$ & $13.3 \%$ & $16.7 \%$ & $13.3 \%$ & $26.7 \%$ & $30.0 \%$ \\
\hline there are monetary and financial benefits & $23.1 \%$ & $30.8 \%$ & $7.7 \%$ & $15.4 \%$ & $23.1 \%$ \\
\hline there is no restriction of working hours & $16.0 \%$ & $12.0 \%$ & $8.0 \%$ & $32.0 \%$ & $32.0 \%$ \\
\hline
\end{tabular}

Those who pursue research career were hopeful that it elevates professional standing. There is increasing realization of research as progressed in academic years. Students in their near graduation phases apprehended the pleasure of taking in research (Table 2). In the contrary, the main reasons for not-pursuing a research career were lack of monetary benefit $(p=0.33)$ and fear of stress in job $(\mathrm{p}=0.057)$ (Table 3$)$.

Table 3: Reasons for not pursuing a career in research

\begin{tabular}{|c|c|c|c|c|c|c|}
\hline $\begin{array}{c}\text { Reasons for not pursuing a career in } \\
\text { research }(n=160)\end{array}$ & 2year & 3year & 4year & 5year & 5year+ & $P=$ value \\
\hline$\ldots$ it is difficult and complex & 33.9 & 26.8 & 14.3 & 14.3 & 10.7 & 0.057 \\
\hline$\ldots$ it is stressful & 36.6 & 29.3 & 17.1 & 9.8 & 7.3 & 0.042 \\
\hline$\ldots$ is time consuming & 28.4 & 23.9 & 28.4 & 10.4 & 9.0 & 0.059 \\
\hline ... i don't like research & 30.6 & 19.4 & 16.7 & 16.7 & 16.7 & 0.481 \\
\hline $\begin{array}{r}\begin{array}{r}\text {... no positive attitude towards research } \\
\text { during university }\end{array} \\
\end{array}$ & 12.5 & 37.5 & 31.2 & 12.5 & 6.2 & 0.424 \\
\hline $\begin{array}{r}\text {... clinical profession is more important } \\
\text { than research }\end{array}$ & 23.4 & 24.5 & 19.1 & 21.3 & 11.7 & 0.791 \\
\hline $\begin{array}{r}\text {... it will not elevate professional standing } \\
\text { as a clinician }\end{array}$ & 20.8 & 16.7 & 25.0 & 16.7 & 20.8 & 0.605 \\
\hline $\begin{array}{r}. . . \text { there are no monetary and financial } \\
\text { benefits }\end{array}$ & 42.9 & 21.4 & 7.1 & 14.3 & 14.3 & 0.033 \\
\hline
\end{tabular}

The principle motives to conduct research in medical school were: being mandatory in the curriculum $(60.1 \%)$, to get hold of job after graduation $(68.4 \%)$ and to pursue a career in research $(42.1 \%)$.

Regarding research supervisor; 87.7\% students had acknowledged getting research supervisor. Regarding the capability and dedication of the supervisor; students viewed that $83 \%$ research supervisors were competent, and $83 \%$ research supervisors were dedicated to favor students in 
research process. If given, $71.5 \%$ students would work with the same research supervisor. The best things students remarked about supervisors is $87.4 \%$ responded that supervisors gave them a positive attitude regarding research. Many students $(57.3 \%)$ retorted that there is no sufficient time in academic calendar to practice research activities. Insufficiency of research infrastructures like research laboratory $(56.5 \%)$ and computer $(55.7 \%)$ are other deterrents. (Table 4$)$

Table 4: Barriers to student research at the university $(\mathrm{N}=253)$

\begin{tabular}{|r|l|}
\hline & Percent \\
\hline Lack of adequate funding for student research & 71.5 \\
\hline Time allocated to student research is insufficient & 57.3 \\
\hline Lack of well-equipped laboratory facilities & 56.5 \\
\hline Lack of well-equipped computer facilities & 55.7 \\
\hline Difficulty in obtaining ethical approval & 47.8 \\
\hline Difficulty in obtaining administrative approval & 46.6 \\
\hline Lack of supportive staff such as biostatisticians, bio-ethicists and proof editors & 41.1 \\
\hline Lack of adequate research and biostatistics curriculum & 36.4 \\
\hline Lack of study subjects or samples for research & 33.2 \\
\hline Lack of competent and committed supervisors & 26.9 \\
\hline Lack of interest in research by faculty & 25.4 \\
\hline
\end{tabular}

Ethical review of research protocol from authorized board is important activities but research respondents (47.3\%) reflected that it discouraging at PAHS. Some respondents $(46.4 \%)$ reacted being inadequate research curricula while other some $(29.4 \%)$ viewed lack of competent and committed supervisors at PAHS. Respondents also viewed that about one-fourth faculties are not interested to support in research. (Table 4)

Table 5: The mean score of perceptions, motives and barriers to research based on academic level of respondents

\begin{tabular}{|c|c|c|c|c|c|c|c|}
\hline & $\begin{array}{c}\text { Perceptions } \\
\text { towards } \\
\text { research } \\
\mathbf{( 5 )}\end{array}$ & $\begin{array}{c}\text { Motives to } \\
\text { conduct } \\
\text { research } \\
\mathbf{( 3 )}\end{array}$ & $\begin{array}{l}\text { Reasons for } \\
\text { pursuing a } \\
\text { career in } \\
\text { research (4) }\end{array}$ & $\begin{array}{c}\text { Reasons for } \\
\text { not } \\
\text { pursuing a } \\
\text { career in } \\
\text { research }\end{array}$ & $\begin{array}{c}\text { Competency \& } \\
\text { commitment of } \\
\text { the research } \\
\text { supervisor }\end{array}$ & $\begin{array}{c}\text { Training in } \\
\text { research at } \\
\text { the PAHS }\end{array}$ & $\begin{array}{c}\text { Barriers to } \\
\text { student } \\
\text { research at } \\
\text { PAHS }\end{array}$ \\
\hline 2year & $4.50 \pm 0.79$ & $1.43 \pm 0.87$ & $1.50 \pm 0.87$ & $2.92 \pm 1.75$ & $6.68 \pm 2.36$ & $2.45 \pm 0.83$ & $5.75 \pm 3.28$ \\
\hline 3year & $4.09 \pm 0.90$ & $1.67 \pm 0.67$ & $2.75 \pm 1.24$ & $2.32 \pm 2.03$ & $8.06 \pm 1.80$ & $2.35 \pm 0.70$ & $5.63 \pm 3.13$ \\
\hline 4year & $4.00 \pm 0.86$ & $1.76 \pm 0.80$ & $2.14 \pm 0.95$ & $1.97 \pm 1.63$ & $7.20 \pm 2.07$ & $2.66 \pm 0.56$ & $6.24 \pm 2.70$ \\
\hline 5year & $4.28 \pm 0.72$ & $1.75 \pm 0.70$ & $2.68 \pm 0.95$ & $1.77 \pm 1.77$ & $7.04 \pm 2.59$ & $2.53 \pm 0.61$ & $7.53 \pm 3.19$ \\
\hline 5year + & $4.38 \pm 0.77$ & $1.98 \pm 0.77$ & $3.08 \pm 1.10$ & $2.21 \pm 2.01$ & $7.48 \pm 2.51$ & $2.53 \pm 0.64$ & $6.95 \pm 3.54$ \\
\hline Total & $4.25 \pm 0.82$ & $1.70 \pm 0.78$ & $2.65 \pm 1.12$ & $2.26 \pm 1.85$ & $7.28 \pm 2.30$ & $2.50 \pm 0.68$ & $6.38 \pm 3.22$ \\
\hline$P=$ value & 0.012 & 0.013 & 0.248 & 0.105 & 0.027 & 0.216 & 0.010 \\
\hline
\end{tabular}

The correlation of the mean score of seven different domains with academic level of the respondents was calculated. The perceptions towards research (0.012), motives to conduct research (0.013), competency and commitment of the research supervisor (0.027) and barriers to students (0.010) were significant. (Table 4) 


\section{Discussion}

Our study among 253 undergraduate medical students has revealed that $87.7 \%$ had not involved in research prior to medical school. Although majority $(94.1 \%)$ of respondents viewed that research is important in medical education which counter conventional mind-set of medical curriculum in some developing countries (Majumdar, 2004), (Burgoyne, 2010), (Komenda, 2015).

The study has professed that conducting research during medical school is important. As the respondents advanced in academy program, the stances towards research increased (Khan, 2009), (Memarpour, 2015). More than three quarter (78.3\%) have viewed that medical curriculum is very demanding thus key barriers to student's research is lack of allocated time for research $(61.7 \%)$, well-equipped laboratory and computers. They have also pin-pointed that obtaining ethical approval (47.8\%), administrative approval from concern departments and respondents (46.6\%) and supportive staff such as bio-statisticians $(41.1 \%)$ are other genuine barriers to students at PAHS. The findings are similar with study done in other countries. (Lavis, 2008), (Vereijken, 2017), (Marzo, 2017). The medical curriculum is physically and mentally demanding and the frequent exams force students to prioritize the major demands of the curriculum ahead of research activities (Devasiri, 2007). Respondents have uttered that conducting research work during undergraduate program have three purposes; placement in preferred post-graduation program (68.4 $\%$ ), meet accreditation requirement $(60.1 \%)$ and pursue a research career $(42.1 \%)$. These findings are comparable with other studies from Asian countries (Chaturvedi, 2001) (Aslam, 2005), (Marzo, 2017).

The study revealed that majority $(73.5 \%)$ respondents found faculties interested to facilitate research but many time (59.3\%) students compromise research supervision (Petrella, 2008). There were around one-third faculties $(38.7 \%)$ who were less competent and less committed to facilitate in research process.

The study findings are limited to a single institute and there may be biases due to self-reporting result design. The dichotomous responses to questions may have rule out variance in responses. The research questionnaire was adopted from Sudan study and administered are some limitation of this study.

\section{Limitations}

There were several limitations to our study. The sampling site was one medical academy hence; we may not generalize the findings. The study finding was drawn from volunteer responses of medical students out of all current students that may upshot some degree of bias.

\section{Application of Research Findings}

The findings of this research will baseline information to assess the value of research from student's perspective. The accreditation body of medical education can take appropriate measures to raise the standards research knowledge and practice among medical students. It is evidenced that research skills to medical students not only improve scientific process, infer results, explain 
results and apply as appropriately (Bennett, 2016), (Stone, 2018) but also improvised clinical services.

\section{Conclusion}

Our study focused on the perceptions, attitudes and barriers and guidance of medical students towards research. The result shows that students perceived research as worth doing and contributing in future career. There is mix perception towards research among students. Gaps should be addressed to improve research perceptions, careers prospects and boost up overall academic performance. Despite its high value, research work does not attract many medical students. Academic institution needs to create enabling environment to attract more numbers of students to pursue research career. Allocating a fixed-time in the academic calendar for student research and research supervisors may minimize major obstacle and enable more interaction between students and their supervisors. The findings of this survey can further instigate to improvise the curriculum as well as research activities.

\section{Acknowledgments}

Great appreciation is extended to the undergraduate medical students for their time to fill-up the research questionnaire. Our gratefulness goes to PAHS authorities for granting permission to conduct the survey. I am grateful to Tarig Osman who provided the research tool applied to conduct research among Sudanese Health Sciences Students in 2016.

Funding - The research was self-funded by the author.

Author's Contribution - SP designed the proposal, research tools, data collection, data cleaning, create dummy tables. KGC generate tables. SP prepare first manuscript. SP, KGC, BKMA contributed to finalization the manuscript.

Ethical Approval - Article has been approved from Patan Academy of Health Sciences.

\section{Conflict of Interest - No.}

\section{References}

[1] Abu-Zaid A, Alkattan K. (2013) Integration of scientific research training into undergraduate medical education: a reminder call. Med Educ Online.18(1):22832.

[2] Alghamdi K.M, Moussa N.A., Alessa D.S., Alothimeen N, Al-Saud A.S. (2014). Perceptions, attitudes and practices toward research among senior medical students. Saudi Pharm J. 22(2):1137.

[3] APEC. (2010). Skills and competencies needed in the research field objectives 2020. DELOITTE Consulting Public Sector: 0140882246 / www.deloitte.com

[4] Aslam F, Shakir M, Qayyum MA. (2005). Why Medical Students Are Crucial to the Future of Research in South Asia. PLoS Medicine. Volume 2 | Issue 1

[5] Bennett C. (2016). Why all medical students need to experience research? Aust Med Student J. 4; [cited 2017 Nov 11]. Available from: http://www.amsj.org/archives/4796

[6] Burgoyne L.N, O’Flynn S, Boylan G.B. (2010). Undergraduate medical research: the student perspective. Med Educ. Online. 10, 15 
[7] Chaturvedi, S., Aggarwal, O.P. (2001). Training interns in population-based research: learners' feedback from 13 consecutive batches from a medical school in India. Med. Educ. 35 (6), 585-589.

[8] DeFranco DB, Sowa G. (2014). The importance of basic science and research training for the next generation of physicians and physician scientists. Mol Endocrinol. 28(12):1919-1921.

[9] Devasiri D, Bodinayake C. (2007). Integrated Medical Curriculum: need of introducing clinical medicine in the first year of teaching. Galle Medical Journal, Vol. 12: No.1,

[10] Donika, A.D. (2015). The study of professional deformations of doctors as deviations of their professional role. International Journal of Emergency Mental Health and Human Resilience, Vol. 17, No.4 ISSN 1522-4821

[11] Gharaibeh A, Mousa Y.S. (2014). Should research thesis be a prerequisite for doctor of medicine degree? a cross-sectional study at Jordan university of science and technology. Int J Med Stud. 2(1):8-12.

[12] Khan H, Khan S, Iqbal A. (2009). Knowledge, attitudes and practices around health research: the perspective of physicians-in-training in Pakistan. BMC Med Educ. 9:46

[13] Komenda M, Víta M, Vaitsis C, et al. (2015). Curriculum Mapping with Academic Analytics in Medical and Healthcare Education. PLoS ONE. 10(12): e0143748. doi:10.1371/journal.pone.0143748

[14] Lavis J.N., Oxman A.D., Moynihan R., Paulsen E.J. (2008). Evidence-informed health policy 1Synthesis of findings from a multi-method study of organizations that support the use of research evidence. Implement Sci. 3,53.

[15] Lloyd T, Phillips BR, Aber RC. (2004). Factors that influence doctors' participation in clinical research. Med Educ 38(8):848-851.

[16] Majumdar, M.A.A. (2004). Issues and priorities of medical education research in Asia. Annals Academy of Medicine vol. 33 No. 2.

[17] Marzo R.R., Maged E., Shalini G., Sundrasegaran S., (2017). Perception and attitudes of medical students towards research and survey. Int. J. of Allied Med. Sci. and Clin. Research Vol-5(1) 217229

[18] McGregor S, Henderson KJ, Kaldor JM. (2014). How are health research priorities set in LMIC? A systematic review of published reports. PLoS ONE 9(10): e108787. doi:10.1371/journal.pone.0108787

[19] Memarpour M, Fard AP, Ghasemi R. (2015). Evaluation of attitude to, knowledge of and barriers toward research among medical science students. Asia Pacific Family Medicine 14:1 DOI 10.1186/s12930-015-0019-2

[20] Nuyens Y. (2007). Setting priorities for health research: lessons from low- and middle-income countries. Bulletin of the World Health Organization. 85 (4)

[21] Oliveira C.C, de Souza RC, Abe E.H.S, Móz L.E.S, de Carvalho L.R, Domingues M.A. (2013). Undergraduate research in medical education: a descriptive study of students' views. BMC Medical Education 14:51

[22] Osman T. (2016) Medical students' perceptions towards research at a Sudanese University. BMC Medical Education 16:253 DOI 10.1186/s12909-016-0776-0

[23] Patan Academy of Health Sciences Act (2008). Government of Nepal www.pahs.edu.np

[24] Petrella JK, Jung AP. (2008). Undergraduate Research: Importance, Benefits, and Challenges. Int J Exerc Sci 1(3) : 91-95. http://www.intjexersci.com

[25] Reinders JJ, Kropmans TJ, Cohen-Schotanus J. (2005). Extracurricular research experience of medical students and their scientific output after graduation. Med Educ. 39(2):237.

[26] Siemens, D. R., Punnen, S., Wong, J., Kanji, N.. et.al. (2010). A survey on the attitudes towards research in medical school. BMC Medical Education, 10(4), 1-7. http://dx.doi.org/10.1186/14726920-10-4

[27] Silcox LC, Ashbury TL, VanDenKerkhof EG, Milne B. (2006). Residents' and program director's attitudes toward research during Anesthesiology training: A Canadian Perspective. Anesthesia and Analgesia 102:859-864. 
[28] Solomon SS, Tom S.C, Pichert J, Wasserman D, Powers A.C. (2002). Impact of medical student research in the development of physician-scientists. J Investig Med 51(3):149-156.

[29] Stone C, Dogbey GY, Klenzak S, Van Fossen K, Tan B, et.al. (2018). Contemporary global perspectives of medical students on research during undergraduate medical education: a systematic literature review. Medical Education Online 23:1, 1537430, DOI:10.1080/10872981.2018.1537430

[30] Vereijken MWC, van der Rijst RM, van Driel JH, Dekker FW. (2017). Student learning outcomes, perceptions and beliefs in the context of strengthening research integration into the first year of medical school. Adv in Health Sci Educ. Springer. DOI 10.1007/s10459-017-9803-0

[31] World Federation for Medical Education. (1998). International standards in medical education: assessment and accreditation of medical schools educational programs. A WFME position paper. Med Educ 32: 549_58.

[32] Zier K, Friedman E, Smith L. (2006). Supportive programs increase medical students' research interest and productivity. J Investig Med 54:201-7.

*Corresponding author.

E-mail address: sudarshanpaudel @gmail.com 